\title{
O CASO DOS BINGOS ELETRÔNICOS À LUZ DA LEI DE IMPROBIDADE ADMINISTRATIVA*
}

\author{
JOSÉ GUILHERME GIACOMUZZI**
}

1. Breve escorço dos fatos - 2. Imputação de improbidade pelo relatório final - 3. Apreciação do mérito - (i) Da "denúncia" do $\mathrm{MJDH}$ peça-motor das conclusões da CPI - (ii) $O$ caos normativo acerca da matéria "jogos de azar" - disputa entre as esferas de governo para angariar recursos - (iii) A legislação estadual sobre "jogos de azar" - Os Decretos Estaduais/RS 40.593, 40.635 e 40.765. e as Instruções Normativas 01 e 02/2001 - tentativa de normatização do "bingo" $e$ delimitação do objeto desta análise - (iv) Sobre a (i)legialidade dos "jogos de azar" - Falta do elemento subjetivo da improbidade na edição de atos administrativos normativos - 4. Resumo e considerações finais

\section{Breve escorço dos fatos}

Comissão Parlamentar de Inquérito da Segurança Pública havida na Assembléia Legislativa do Estado do Rio Grande do Sul no ano de 2001 resolveu por indiciar,

* O escrito é, com mínimas adaptações, cingidas a correções de gramática, a promoção de arquivamento feita pelo autor no Expediente $n^{\circ}$ SPI 16564-0900/01-2/G, datada de 28.01.2002, acolhida em 29.01.2002 pelo então DD. Procurador-Geral de Justiça do RS, Cláudio Barros Silva, e homologada, em decisão unânime, pelo Conselho Superior do Ministério Público do RS em 22.04.2003. Cuida-se da análise de parte dos fatos apurados pela chamada "CPI da Segurança Pública", realizada na, Assembléia Legislativa do RS no segundo semestre de 2001, a qual acabou por indiciar o então Governador do Estado, Sr. Olívio Dutra, e outros tantos, por ato de improbidade administrativa, além de vários outros ilícitos. O Expediente $n^{\circ}$ SPI 16564-0900/01-2/G cuida somente do problema relativo à regulamentação dos bingos eletrônicos. Os demais indiciamentos, correspondendo a outros fatos, foram, por razões de necessidade na investigação e de racionalidade, desmembrados, no âmbito interno do Ministério Público do RS, em vários outros expedientes, que receberam cada qual análise em separado.

** Mestre e doutorando em Direito (UFRGS); Master of Laws student (George Washington University - USA); Bolsista da CAPES; Promotor de Justiça no RS; Professor na PUC/RS. 
no seu Relatório Final (RF-CPI), encaminhado ao Ministério Público do Estado do RS (MPE) em 10.12.2001, o DD. Governador Estado e outros por uma série de ilícitos penais e civis lato sensu.

Uma vez na Procuradoria-Geral de Justiça os autos, os vários fatos apontados no RF-CPI foram apreciados separadamente, distribuídos entre os vários Promotores de Justiça designados pela Portaria 0228/2002 do DD. Procurador-Geral ao exame a matéria. Este expediente cuida do fato relativo aos "jogos eletrônicos", tendo havido, no RF-CPI, indiciamento, por ato de improbidade administrativa, do DD. Governador do Estado, Sr. OLÍVIO DUTRA, do DD. Vice-Governador do Estado, Sr. MIGUEL ROSSETO, do DD. Chefe da Casa Civil, Sr. FLÁVIO KOUZTII, do DD. Subchefe, Sr. GUSTAVO MELLO, e também do DD. Secretário da Fazenda, Sr. ARNO AUGUSTIN, além dos Diretores da LOTERGS, ANTÔNIO CARLOS CONTURSI e JOSÉ VICENTE GOULART BRIZOLA.

Esse é o fato ora apreciado, por designação da Portaria 007/2002 - CPI do DD. Procurador-Geral de Justiça, compondo o expediente $n^{\circ}$ SPI 16564-0900/012/G.

\section{Imputação de improbidade pelo relatório final}

Segundo o RF-CPI, os indiciados teriam infringido o art. 11, caput, e incisos I, III e VII, da Lei Federal n ${ }^{\circ} 8.429 / 92$ - chamada Lei de Improbidade Administrativa (LIA). Isso porque, em suma, teriam os indiciados, ao tentar regulamentar a prática dos jogos eletrônicos no Estado do RS, violado os deveres de honestidade, legalidade e moralidade no exercício de mandato ou cargo público, mormente via edição de Decretos Executivos - ns. 40.593 e 40.765 , de 16.01 .01 e 20.02 .01 - e das Instruções Normativas LOTERGS ns. 1 e 2, de 19 e 20.02.01.

A edição de tais Decretos e Instruções Normativas seria inconstitucional, uma vez que a competência a legislar sobre a matéria, diz o RF-CPI, seria da União Federal, forte art. 22, XX ("sistemas de consórcios e sorteios"). E, somando-se a isso, estariam comprovadas ligações entre representantes do "jogo" e as autoridades da LOTERGS e do Governo do Estado, daí concluindo o RF-CPI que os Decretos e as Instruções Normativas teriam sido editados a fim de favorecer determinadas pessoas, revelando atos ímprobos de todos os que participaram, de alguma forma, da edição de tais normas.

\section{Apreciação do mérito}

Não se vislumbra improbidade administrativa nos fatos apurados pela CPI relativamente aos "jogos eletrônicos", no que toca aos atos administrativos normativos (Decretos e Instruções Normativas) investigados.

A apreciação da matéria comporta algumas digressões acerca dos fatos que originaram a conclusão da CPI, bem como sobre a legislação que rege o problema dos "jogos de azar" e assim também sobre os atos de suposta improbidade, perpassando pela natureza do ato ímprobo. 
(i) Da "denúncia" do MJDH - peça-motor das conclusões da CPI

É importante frisar que a peça-motor do indiciamento sobre os "jogos eletrônicos" foi uma "denúncia", subscrita pelo Movimento de Justiça e Direitos Humanos (MJDH) e entregue à CPI em 20 de junho de 2001, que relatava fatos em tese graves:

“(...) a existência de grupos controladores de jogatina clandestina (caçaniqueis, jogo do bicho. sistemas on-line real times de apostas), com ramificações nacionais e internacionais que atuam junto ao Governo gaúcho, com a intenção de introduzir, por meio de dispositivos pretensamente legais - como decretos que invadem a competência legislativa da União - as mais diversas modalidades de exploração de jogos de azar no Rio Grande do Sul".

Essa "denúncia" foi entregue à CPI acompanhada de alguns documentos, um dos quais uma cópia da ação de improbidade administrativa movida pelo Ministério Público Federal (MPF) contra o ex-Ministro dos Esportes, Sr. Rafael Grecca, e outros réus. Anote-se que referida ação, no entanto, não foi repassada a este Ministério Público Estadual (MPE) quando da entrega dos documentos pela CPI, o que por certo prejudicou, a princípio, a análise dos fatos, uma vez que o conhecimento do teor da referida ação é em tudo relevante à apreciação isenta da matéria.

$O$ descuido no não-envio da dita ação de improbidade do $M P F$ a esta instituição - que, por comando Constitucional ( $\mathrm{CF}$, art. $\left.58, \S 3^{\circ}\right)$, é a destinatária das conclusões de toda $\mathrm{CPI}$ - é digno de nota, considerando que vários outros documentos, nem todos importantes, foram entregues junto ao RF-CPI (depoimentos, ofícios, termos de degravações de escutas telefônicas, disquetes, quebras de sigilos bancário e telefônicos), inclusive a própria "denúncia" do $\mathrm{MJDH}$, mas não aquela ação de improbidade, que, depois buscada, se viu ser datada 19 de outubro de 1999 e conter mais de duzentas laudas.

Naquela ação, o MPF, em hercúleo trabalho investigatório, discorre sobre a relação de membros do alto escalão do Governo Federal com a máfia italiana e os jogos de azar, tendo-se valido inclusive, para as suas conclusões, de prova emprestada obtida junto ao Ministério Público da Itália - Procuradoria Nacional Antimáfia. O trabalho do MPF põe a nu as relações da máfia italiana com os jogos de azar, explicando, com riqueza de detalhes, os meandros do poder daquela organização e suas formas de ação para acobertamento das muitas formas de ilícito por ela praticadas, indicando minudentemente as relações com a cúpula do Governo Federal, na pessoa do ex-Ministro Rafael Grecca e seus apadrinhados políticos.

De fato impressiona a leitura da referida ação. Ao fazê-lo, não se percebe, entretanto, uma palavra sequer alusiva a eventual ramificação das ilicitudes com agentes públicos gaúchos.

Diga-se, por relevante, que nas quarenta e oito reuniões da CPI da Segurança Pública, que tomou, segundo o RF-CPI, 157 depoimentos, não tenha havido, por parte dos Digníssimos Parlamentares, insistência ou mesmo menção ou manifestação todas degravadas e públicas - que indique claramente terem os DD. Deputados lido ou tido conhecimento do teor da ação de improbidade do MPF. 
Foi necessária a expedição, por este MPE, de ofício, em 09.01.2002 (Of. SUBINST $n^{\circ} 004 / 2002$ ), ao MPF para que fossem prestados esclarecimentos acerca dos fatos, mormente buscando perquirir se, da investigação havida naquela instituição, algum indício de participação de autoridades gaúchas com as ilicitudes praticadas existia. A resposta do MPF, subscrita pelo Procurador da República Luiz Francisco de Souza, recebida hoje (OFÍCIO/MPF/PRDF/LF No 25), dá conta do seguinte: "Não foi vislumbrada nenhuma vinculação entre a Máfia italiana ligada aos bingos, que opera no Brasil, e o Governo do Estado do Rio Grande do Sul".

Após mencionar que a vinculação se deu com o Governo Federal e transcrever partes do pedido de quebra de cerca de 60 sigilos bancários e telefônicos, o DD. Procurador da República conclui, com grifos no original:

"Conclusão: os extratos acina transcritos mostram as ligações das empresas ligadas à Máfia com o Ministério dos Esportes e Turismo e com a CONAB, órgão do Ministério da Agricultura. Logo, ligações com o Governo Federal. A petição inteira segue pelo correio."

"Durante as investigações, e mesmo depois, esta Procuradoria não achou sequer indicios sobre ligações com o Governo do Estado do Estado do Rio Grande do Sul. Absolutamente nada."

No entanto, é também verdadeiro que do fato de ter o MPF informado que não encontrara, na sua exaustiva investigação, elementos que evidenciassem ou mesmo meramente apontassem para o envolvimento de agentes públicos gaúchos nos graves ilícitos investigados no âmbito federal acerca dos "jogos" não se pode deduzir tout court que esse envolvimento não existiu e que não possa ter havido, também aqui no RS, eventual prática de ato de improbidade administrativa na edição de atos administrativos normativos por parte das autoridades estaduais investigadas. Proceder assim seria tão simples quanto ingênuo. Daí a necessidade de análise dos elementos colhidos pela CPI e das razões do indiciamento neste tocante.

(ii) O caos normativo acerca da matéria "jogos de azar" - disputa entre as esferas de governo para angariar recursos

A leitura dos documentos oriundos da CPI, principalmente a análise dos debates dos seus membros quando em discussão o problema dos "jogos de azar", mostra claramente que o tema era, se não totalmente estranho, ao menos não inteiramente conhecido dos ilustres Deputados. E é natural que assim seja, ante a complexidade do assunto, nos planos fático e normativo.

A análise dos motivos dessa confusão passa também - mas não só - pela pluralidade de nomes genéricos que se dá ao tema e pelo caos normativo do problema “jogos de azar”. É necessário que se faça rápida distinção de termos, a fim de melhor compreender o que tratavam os famigerados Decretos Estaduais 40.593, $40.635 \mathrm{e}$ 40.765 , todos de 2001 , e o que têm eles a ver com o problema dos "jogos de azar", 
bem como é importante esclarecer que temáticas são por eles englobadas e onde eles se situam no ordenamento jurídico.

"Jogo de azar", diz a Lei de Contravenções Penais (LCP), é aquele em que "o ganho e a perda dependem exclusiva ou principalmente da sorte" (art. 50, $\S 3^{\circ}$, ' $a$ ', Dec.-lei 3.688/41) e, pode-se dizer, é o nome genérico, do qual os demais são espécies - passando pelo "jogo do bicho" e até os familiares "pif paf", "truco", "bozó", "vinte e um" e tantos outros, os bingos inclusive, mesmo os eletrônicos.

Com isso não se está a dizer que o "pif paf" e os demais sejam "jogos de azar" e que merecem a punição da LCP. Somente se está em nível de nomenclatura.

A jurisprudência sempre vacilou na temática acerca de sua licitude, bastando a consulta a qualquer repertório. No RE 24.095, julgado em 03.01.1953, o Supremo Tribunal Federal fazia alusão ao fato de que a legislação brasileira, tendo dado aos "jogos de azar' definição ampla, tinha deixado "à jurisprudência, isto é, aos Juizes e Tribunais, o encargo de solucionar a matéria ou elucidar o assunto". O caso discutido dizia com a caracterização, ou não, do "cook can play" como jogo de azar, e, à época, peritos da polícia técnica dos Estados de São Paulo e do Rio Grande do Sul, após longos exames - isso tendo sido mencionado no acórdão pelo Relator Ministro Lafayette de Andrada -, concluíra que o "cook can play" e o "pif paf" eram jogos de azar.

No entanto, o Tribunal de Justiça do Distrito Federal, em 18.05.1953, na Ap. $\mathrm{n}^{\circ} 12.264$ decidia, com base "em reiterada jurisprudência do Supremo Tribunal Federal", que o "pif-paf", como o poker, não podia ser considerado jogo de azar, pois "não dependia exclusivamente da sorte".

O problema das "loterias" - que é também um jogo de azar - recebeu da LCP tratamento em tipos penais específicos (arts. 51 a 57), sob a denominação "loteria não autorizada". No entanto, com o advento do Dec.-Lei 6.259 , de 10.02.1944, de cunho administrativo e que definiu novamente as mesmas loterias, mas não explicitou - diz

WILSON NINNO ${ }^{1}$ - se revogava os artigos anteriores da LCP nem aludiu se os esses passariam a ter nova redação, desenvolveram-se três correntes de pensamento: os que aplicavam a LCP, os que aplicavam o Dec.-lei 6.259/44 e os que aplicavam ambos. Uma verdadeira "balbúrdia legislativa e jurisprudencial", nas palavras de WILSON NINNO.

Para os limites desta análise é relevante notar ser certo que tanto a LCP quanto o Dec. lei 6.259/44 continham tipos penais referentes a loterias estaduais, isto é, não somente de âmbito federal - talvez admitindo, implicitamente, sua licitude. Com efeito, o art. 53 da LCP e os arts. 46, 48 e 50 do Dec.-lei 6.259/44 tornavam ilícita a conduta de introduzir bilhetes de loteria estadual onde não podia legalmente circular. Passou-se a discutir o âmbito territorial de circulação das loterias (se o bilhete de loteria de um Estado poderia circular no de outro), com decisões para todos os gostos.

1 NINNO, Wilson. Leis Penais Especiais e Sua Interpretaçāo Jurisprudencial, (Alberto Silva Franco e outros), Sāo Paulo: RT, 1995, p.229 
Escolhe-se e fez-se mínimas alusões a esses dois pontos - caracterização ou não de uma atividade como "jogo de azar" e existência ou não de normatização estadual da matéria - não por acaso, mas sim porque foram pontos debatidos durante a CPI: se era possível ou não a normatização estadual sobre "jogos de azar", se o jogo nas máquinas caça-níquel eram ou não lícitas, se podiam ou não ser apreendidas pela Polícia, e outros afins.

É importante atentar ao seguinte ponto: nunca se navegou em águas serenas nessas temáticas. Arrisco a causa: o assunto é interdisciplinar e envolve muitos interesses (econômico-privados, sociais, culturais, fiscais, dentre os quais estão inclusive pessoas ligadas a atividades ilícitas, que pretendem torná-las lícitas) e inúmeros fatores e realidades (quais jogos devem ser lícitos e quais ilícitos, quais as suas causas e consequiências psicológicas, antropológicas, sociológicas). O “jogo" (inclui-se aqui a loteria), lícito ou ilícito, é realidade mundial e acompanhou a história do homem, e entre nós não é diferente.

Há quem veja no "jogo" a raiz de muitos dos males sociais. ANTONIO CELSO C. DE OLIVEIRA FARIA é enfático ao conclamar: "é importante que a sociedade tome consciência dos malefícios ocasionados pelos jogos de azar, incluindo-se nesse conceito os bingos e as máquinas caça-níqueis". E invoca BENTO DE FARIA, que por sua vez cita as candentes palavras de RUI BARBOSA:

"O jogo, o grande putrefactor, é a sintese cancerosa das raças ameninadas pela sensualidade e pela preguiça; ela entorpece, caleja, desviriliza os povos, nas fibras de cujo organismo insintou o seu germen proliferante e inextirpável. Só o jogo não conhece renitências: com a mesma continuidade com que devora as noites do homem ocupado e os dias do ocioso, os milhões do opulento e as migalhas do operário, tripudia uniformemente sobre as sociedades nas quadras de fecundidade e de penúria, de abastecimento e de fome, de alegria e de luto".?

É fácil ver que o "jogo", aqui, é empregado de forma genérica. Todo e qualquer jogo seria nocivo.

Mas existe quem trate da matéria com menos ênfase retórica, entretanto. ÁLVARO MELLO FILHO, que em obra recente também lembrou a frase de Ruy Barbosa ${ }^{3}$, já disse, noutro lugar, ser preconceituosa a visão e tendenciosas as campanhas contra os bingos e similares e enumera alguns dos que entende ser "palpáveis e concretos benefícios econômicos e sociais já resultante da atividade de realização de bingos e similares, em suas plúrimas modalidades": criação de cerca de 78.000 novos empregos diretos e indiretos; incremento das receitas da União (Imposto de Renda), dos Estados (taxa de Fiscalização) e dos Municípios (ISS); cumprimento do dever

2 apud FARIA, Antonio Celso Campos de Oliveira, Boletim IBCCrim, ano 7, n 85, p. 11.

3 MELO FILHO, Álvaro. Novo regime juridico do desporto; comentários à Lei 9.615 e suas alterações. Brasília: Brasília Jurídica, 2001, p. 220. 
do Estado insculpido no caput do art. 217 da CF/88; estímulo do Poder Público ao lazer ${ }^{4}$.

À parte princípios morais, sendo o jogo realidade incontrastável, é certo que o Estado - e o Direito - deveria dela se ocupar. E efetivamente o fez, e não de hoje.

Em nível infraconstitucional, de há muito disposições normativas tratavam de disciplinar a matéria ${ }^{5}$, com uma peculiaridade digna de nota: a partir de determinado momento, olhos postos na arrecadação que poderia advir dessa atividade, debateram-se União e Estados pelo controle normativo do jogo.

O Dec. 21.143, de 10.03.1932, consolidou a legislação sobre loterias, em resguardo do "interesse público e da moralidade administrativa", revogando, no art. $1^{\circ}$, "toda a legislação existente sobre loterias, federais ou estaduais". Dito Decreto reconhecia as loterias estaduais (art. $7^{\circ}$ ), circunscrevendo-as ao âmbito dos estados concedentes, mas também as submetia a registro perante o órgão federal próprio (art. 16). Em 24.01.1941, o Dec.-lei 2.980 regulou o serviço de loteria federal e estadual, mantendo a regra territorial de que as loterias estaduais ficariam adstritas aos limites do Estado respectivo (art. $2^{\circ}, \S 1^{\circ}$ ). Sobrevem o Dec.-lei 6.259, de 10.02.1944, que pouco altera a temática.

Digno de nota é o Decreto 9.215, de 30 de abril de 1946, e também seu decorrente 9.250 , de 10 de maio do mesmo ano. O primeiro "proíbe a prática ou exploração de jogos de azar em todo o território nacional". A leitura dos seus considerando é deveras interessante para os fins desta análise.

Com efeito, diz o Decreto 9.215 que "a repressão dos jogos de azar é imperativo da consciência universal' e que "a legislação penal de todos os povos cultos contém preceitos tendentes a esse fim", devendo-se considerar que "a tradição moral, jurídica e religiosa do povo brasileiro é contrária à prática e à exploração dos jogos de azar"; e que "das exceções abertas à lei geral, decorreram abusos nocivos à moral e aos bons costumes". Por isso, e ainda porque as licenças e concessões até então conferidas tinham título precário, resolveu o Sr. Presidente da República da época restaurar a vigência, em todo o território nacional, do art. 50 e parágrafos da LCP (art. $1^{\circ}$ ), revogar os Decretos então em vigor (art. $2^{\circ}$ ) e ainda declarar nulas todas as licenças, concessões ou autorizações dadas pelas autoridades federais, estaduais ou municipais que haviam sido fundamentadas em leis "ora revogadas, ou que, de qualquer forma, contenham autorização em contrário ao disposto no artigo 50 e seus parágrafos da lei das Contravenções Penais" (art. $3^{\circ}$ ). Dez dias após, o Decreto 9.251

4 MELO FILHO, Álvaro. Da constitucionalidade dos bingos desportivos (art. 67 da Lei 8.672/93). Revista dos Tribunais, v. 717, p. 91-100, jul. 1995, p. 92.

5 Boa parte da Legislação citada nesta promoção é retirada de BASTOS, Celso Ribeiro. Dos jogos de bingo por máquinas no país. Revista de Direito Constitucional e Internacional, v. 31, p. 77; e TÁCITO, Caio. Loterias Estaduais (criação e regime jurídico). Revista de Direito Público, vol. 77, pp. 75-79, jan./mar. 1986, p. 76. Anote-se, no entanto, que nem mesmo esses juristas lograram cobrir a matéria, no seu espectro legislativo, com exatidão. Há decretos o $\mathrm{Atros}$ que não foram citados por esses jurisconsuitos. Menciono no texto dois: os Decretos 9.215 , de 30 de abril de 1946, e 9.251, de 11 de maio de 1946. 
vem diminuir os efeitos decorrentes do Decreto 9.215, regulando relações de trabalho vitimadas por força deste último ato.

Era 1946 e via-se já então - isto é importante — a União revogando e anulando atos administrativos dos estados e municípios, em aparente invasão de competências. Posteriormente, por força do Dec.-lei 50.954, de 14.07.1961, a União assume diretamente a exploração da loteria federal, extinta a correspondente concessão, passando o serviço a ser executado pelo Conselho Superior das Caixas Econômicas, em colaboração com as Caixas Econômicas Federais, por intermédio de um órgão especializado, a Administração do Serviço de Loterias Federal (arts. $2^{\circ}$ e $3^{\circ}$ ), recolhendo-se a receita líquida a um fundo especial, que seria destinado ao financiamento de recursos públicos municipais, inclusive de abastecimento de água, e a outras operações de caráter educativo e assistencial (art. 10).

Até aqui, conviveram em harmonia as esferas federal e estadual.

Com o advento do Dec.-lei 204, de 27.02.67, que, no art. $1^{\circ}$, referiu ser a exploração de loterias um serviço público "exclusivo da União", vedando expressamente a criação de loterias estaduais (art. 32), garantidas as já existentes (art. 32, $\S 1^{\circ}$ ), nasce, por conseqüência - ensina CAIO TÁCITO - o monopólio de fato da União com respeito ao serviço de loterias. Tal Decreto, nas palavras do mestre, "inovou profundamente o direito vigente", proibindo a concessão pelos Estados e a sua instituição, o que fez CAIO TÁCITO, à luz da CF/69, dizer: "A norma de exclusividade duplamente ofende o sistema constitucional", porque "viola o princípio da autonomia estadual' e porque "produz monopólio virtual da União dessa atividade", o que seria vedado 6 .

O Dec.-lei 594, de 27.05.69, regulamentado pelo Dec. 66.118, de 26.01.70, instituiu a "loteria esportiva federal", para a exploração de todas as formas de concursos de prognósticos esportivos, destinando a renda obtida a aplicações de caráter assistencial, educacional e de aprimoramento físico. Por seu art. $5^{\circ}$, a loteria ficava sujeita ao pagamento da denominada cota de previdência social, de $10 \%$ sobre a importância bruta de sua receita. A Lei 5.768, de 20.12.1971, disciplinou a distribuição gratuita de prêmios mediante sorteio, vale-brinde, concurso, ou operação assemelhada, a título de propaganda, fazendo-a depender de autorização do Ministério da Fazenda. A Lei 6.905, de 11.05 .1981 , em seu art. $1^{\circ}$, determina a realização, a cada ano, de um concurso de prognósticos esportivos, promovido com base no Dec. lei 594/69, destinando-se a renda à Cruz Vermelha Brasileira, sociedade civil filantrópica. Desde 24.10.1989, já pós-CF/88, com a Lei 7.856, a renda líquida do concurso de prognósticos, no âmbito do Governo Federal, passou a constituir contribuição destinada à seguridade social.

As Leis Zico (Lei 8.672/1993), Pelé (Lei 9.615/1998) e a Lei 9.981/2000 serão depois analisadas.

Anote-se que o dito Dec.-lei 21.143, de 1932, já considerava as loterias federal e estadual como "serviço público" (art. 20), noção complexa e "indecisa em seus 
caracteres", para falar o menos e com RUY CIRNE LIMA7, a qual tem-se prestado a inúmeras controvérsias, que não serão aqui abordadas, sendo consenso somente que as atividades que constituem serviço público variam em época e lugar, segundo as exigências de cada povo ${ }^{8}$, sendo que é “o Estado, por meio do seu Poder Legislativo, que erige ou não em serviço público tal ou qual atividade" 9 .

A par da norma dizer que loteria é serviço público, vale lembrar - sempre no intuito de revelar a polêmica que grassa em qualquer nível nesta temática - a posição contrária e enfática de RUY CIRNE LIMA, que, citando ADAMOVICH e SANTI ROMANO, via no jogo, e em especial nas loterias, uma "imoralidade intrínseca", disparava: "Loteria não é serviço público. PONTES DE MIRANDA disse, excelentemente: 'loterias não são serviço público nem de utilidade pública; são submetidas à permissão, ao regime de fiscalização, em virtude de sua periculosidade para que se proteja, se acautele contra eles o público' (COMENTÁRIOS À CONSTITUIÇÃO DE 1934, Rio de Janeiro, s.d., t. I, p. 421)" 10.

O próprio CIRNE LIMA reconhecia, no entanto, que as loterias eram não raro exploradas pelo Estado como monopólio e, à época, dizia: "Essa é a condição jurídica das loterias no Brasil, federal ou estaduais, assim definida, de resto pelo Decreto-Lei $\mathrm{n}^{\circ} 6.259$, de 10 de fevereiro de 1944 (art. $4^{\circ}$ )" "I . Talvez o mestre gaúcho visse aqui um exemplo à aplicação da máxima pauliana "Non omne quod licet honestum est". Mas isso pouco importa.

O certo é que faz muito que o Estado, permita-se o trocadilho, dá as cartas do jogo, fazendo-o fonte de receita, gostemos ou não, independentemente do que a moral - aqui em tudo relativa - impõe ou signifique. Essa a primeira realidade a ser encarada. O próprio Estado legalizou determinada espécie de "jogo de azar", e dele fez e faz (muito) dinheiro. E tal paradoxo vem servindo de fundamento para algumas decisões dos Pretórios acerca da ilegitimidade da norma penal que incrimina o jogo de azar - JUTACRIM-SP 85/485, 85/382, 84/127, 100/103; RT 605/331, 603/334. Mesmo o nosso TJRS já assim decidiu:

“Descaracterização da contravenção do jogo do bicho porque o Estado carece de autoridade para punir, precisamente por tolerar, autorizar $e$ explorar jogo de azar, além do que a reprovabilidade desta prática só se encontra na lei, mas ausente na consciência da maioria absoluta dos cidadãos. Não há quem não saiba, pois é público e notório que em cada esquina, cada barzinho e praticamente em todas as tabacarias, se realiza o jogo do bicho, no centro da cidade e nos subúrbios, porém só raramente se tem notícia da

7 CIRNE LIMA, Ruy. Princípio de Direito Administrativo Brasileiro, $3^{\mathrm{a}}$ ed., Porto Alegre: Livraria. Sulina, 1954, p.82.

8 Por todos, MEIRELLES, Hely Lopes. Direito Administrativo Brasileiro, $19^{a}$ ed., São Paulo: Malheiros, 1994, p.294.

9 BANDEIRA DE MELLO, Celso Antônio. Curso de Direito Administrativo, 12 ed., 2 tiragem, São Paulo: Malheiros, 2000 , p.587.

10 CIRNE LIMA, Ruy. Pareceres (Direito Público). Porto Alegre: Livraria Sulina, 1963, p.57.

11 idem, ibidem. 
fiscalização e do estouro de uma ou outra, tudo a demostrar a falta de isonomia, a desigualdade constitucional entre certos indivíduos o que repugna a idéia de justiça" - AC, Rel. Érico Barone Pires, RJTJRGS 172/140. (grifei)

Anote-se, entretanto, não ser esta a posição do STJ, o qual entendeu que "A prática de exploração de loterias pelo estado não induz a legalidade da contravenção penal conhecida como jogo do bicho" (RE 127.711/RJ, Rel. Min. Flaquer Scartezzini j. 21.10.1997), sendo também de referir a posição do saudoso Ministro ASSIS TOLEDO, talvez o maior penalista pátrio dos últimas duas ou três décadas, no RE 54.716-4/PR, j. 09.11.94:

\section{PENAL. CONTRAVENÇÃO DO 'JOGO DO BICHO'.}

Acórdão absolutório fundado na perda de eficácia da norma contravencional ('a conduta embora punível deixa de sê-lo socialmente'). Decisão que nega vigência ao art. $58, \S 1^{\circ}$, 'b', do Dec.-lei 6.259/44.

Reconhece-se, em doutrina, que o costume, sempre que beneficie o cidadão, é fonte do Direito Penal. Não obstante, para nascimento do direito consuetudinário são exigíveis certos requisitos essenciais (reconhecimento geral e vontade geral de que norma costumeira atue como direito vigente), não identificável com a mera tolerância ou omissão de algumas autoridades.

A circunstância de o próprio Estado explorar jogos de azar não altera esse entendimento porque, no caso em exame, o que pune é uma certa modalidade de jogo: a clandestina, proibida e não fiscalizada.

Conhecimento do recurso especial do Ministério Público e seu provimento para recebimento da denúncia e seu processamento. (grifei)

Há uma segunda realidade: o "jogo", tratado como contravenção penal desde 1941 pela LCP, tem sido cortina de fumaça ao acorbertamento de outras - e muito mais graves - infrações penais: tráfico de entorpecentes e armas, lavagem de dinheiro e outros.

O Estado vê-se no dilema, portanto, de ter que enfrentar e combater o jogo ilícito, por força da Lei e por imperativos morais, ao mesmo tempo em que explora o jogo (lícito) e dele retira importante fonte de custeio à seguridade social. Se a esse natural paradoxo acrescentarmos os complexos fatores acima referidos sobre o multifatorial conjunto de interesses que devem ser equacionados, percebemos com facilidade que a normatização e o regramento dessa realidade não foi e não é simples. Numa palavra: a par do destino dos valores (receita), de sua correta ou incorreta aplicação, da forma com que são feitos os lobbies para a regulamentação da matéria, o fato é que são milhões e milhões de reais envolvidos sob o singelo signo de "jogos de azar". Uma palavra mal posta aqui ou uma conjunção acolá no regramento movimentam fortunas e geram recursos, líquidos ou não, que todos - Estado inclusive, nas suas várias esferas - querem auferir. Essa a terceira realidade.

As três realidades, conjuntamente interpretadas, produzem o caos normativo, de reflexo social e jurisprudencial, como que relação inevitável de causa e efeito. 
A história normativa da regulamentação dos famigerados "jogos" e loterias não se deu linearmente, como se viu. Após a CF/88, a mesma disputa acerca da competência normativa sobre a matéria persiste. E, além dessa disputa, ainda não resolvida, outro problema surge, na esteira da modernização e da informática: a possibilidade de existência de novos "jogos de azar", quais sejam, os bingos eletrônicos ou máquinas caça-níqueis (também ditos videoloterias).

Mas insista-se, para não perdermos o "fio vermelho": tudo pode ser em verdade tratado, genericamente, como "jogo de azar": jogo do bicho, bingos, loterias ${ }^{12}$. E só alguns deles, no entanto, são explorados pelo Estado.

Anote-se, neste passo, uma peculiaridade: as novas legislações que se seguem à $\mathrm{CF} / 88$ passam a cuidar mais especificamente da temática dos "bingos", deixando de mencionar expressamente "loterias" ou congêneres. Arrisca-se uma explicação sobre o fato: são os bingos (eletrônicos ou não) as novas modalidades de "jogo de azar". Os "bingos" vêm pululando na sociedade, gerando toda uma série de consequiências, dentre elas fatos lícitos e ilícitos e, dentre estes, os mais e os menos graves. E que tais "bingos eletrônicos" vêm sendo modernamente usados para lavagem de dinheiro por entidades internacionais, como mostra com clareza a ação de improbidade do MPF.

Em meio a tudo, persiste a necessidade de regular a temática por normas claras e inequívocas.

Pois bem. Aqui entram as três mais recentes Legislações sobre o assunto: a Lei 8.672/1993 (Lei Zico); a Lei 9.615/1998 (Lei Pelé), que expressamente revogou a Lei Zico (art. 96); e a Lei 9.981, de 14 de julho de 2000, que, quanto aos bingos, revogou expressamente, a partir de 31.12.2001, todos os dispositivos da Lei Pelé (art. $2^{\circ}$ ) e conferiu ao INDESP o credenciamento e à Caixa Federal a autorização e a fiscalização dos bingos (art. $2^{\circ}$, parágrafo único).

Não é necessário que se discorra minudentemente sobre os conflitos existentes entre as Leis Zico, Pelé e a Lei $9.981 / 2000$. Para os nossos fins, importa dizer que a primeira conferia aos Estados a competência para fiscalizar as atividades de "bingo ou similar" (art. $57 \mathrm{e} \S 1^{\circ}$ ). A Lei Pelé - em vigor até 31.12.2001, repita-se -, em contraste com a Lei Zico, reservou o capítulo IX ao "Bingo" (arts. 59 a 81), dizendo-o "permitido em todo o território nacional nos termos desta Lei" (art. 59) e dando à União a atribuição de credenciamento das atividades de bingo permanente ou eventual (art. 60), abolindo a expressão "e similar" da Lei Zico e deixando, a meu ver absolutamente claro, no art. 73 , ser "proibida a instalação de qualquer tipo de máquina de jogo de azar ou de diversões eletrônicas nas salas de bingo", ainda repisando, no art. 74, que "nenhuma outra modalidade de jogo ou similar, que não seja o bingo permanente ou eventual, poderá ser autorizada com base nesta lei". A Lei Pelé também previa tipos penais (art. $75,77,79,80$ e 81$)^{13}$. A última, Lei

12 BARROSO, Luiz Roberto. Natureza jurídica da atividade lotérica, p. 272, diz ser "singela demonstração" que o jogo do bingo é uma espécie do gênero loteria.

13 Sobre a Lei Pelé e sua tentativa de regulamentação dos bingos, ver MELO FILHO, (nota 3), pp. 212 e ss. Melo Filho apanha bem a curiosidade de que a Lei Zico dispensava somente um artigo aos bingos (art. 57), enquanto a Lei Pelé, de 96 artigos, dedicava-lhes 24, isto é, 25\%, aduzindo 
$9.981 / 2000$, coroando o caos normativo, revoga expressamente, no art. $2^{\circ}$, " a partir de 31 de dezembro de 2001, os arts. 59 a 81 da Lei 9.615, de 24 de março de 1998, respeitando-se as autorizações que estiverem em vigor até a data de sua expiração", dizendo, no parágrafo único do mesmo artigo, que "caberá ao INDESP o credenciamento das entidades e a Caixa Econômica Federal a autorização e a fiscalização da realização dos jogos de bingo, bem como a decisão sobre a regularidade das prestações de contas."

Inúmeros debates podem-se seguir acerca da sucessão de leis no tempo, inclusive sob a ótica penal, e suas consequiências jurídicas. Sob a ótica do direito intertemporal, poder-se-ia perguntar, v.g., sobre eventual direito adquirido daqueles que confiavam na permanência da Lei Zico e agiram conforme a boa fé - e mesmo obtiveram licença, vamos admitir - para a exploração de bingos "ou similares" junto aos seus Estados membros ${ }^{14}$. Ou sobre a possibilidade de norma estadual servir como despenalizadora dos tipos de infração penal vigentes. Ou ainda acerca da estranha figura da abolitio criminis "futura" que acabou por nascer da revogação conjunta, pelo art. $2^{\circ}$ da Lei 9.981/2000, de todos os artigos da Lei Pelé que tratavam sobre bingo, inclusive os que estabeleciam novos tipos penais ${ }^{15}$

Além dessas questões, anote-se que sobrevieram dois Decretos Federais a regulamentar a Lei Pelé $\left(n^{\circ} 2.574\right.$, de 29.04.1998) e a Lei $9.981 / 2000\left(n^{\circ} 3.659\right.$, de 14.11.2000), além de uma medida provisória (1.926, de 22.10.1999). O primeiro Decreto (2.574/98) é mais abrangente, mas, no que toca aos bingos, foi completamente revogado pelo segundo (3.659/2000), aliás em obediência à Lei 9.981/2000, que revogara a Lei Pelé por completo no que diz com essa matéria.

Em resumo, o que se tem em vigor, hoje, no Brasil, em nível Federal, é o Decreto 3.659/2000. No seu art. $1^{\circ}$, o Decreto novamente caracteriza o jogo de bingo como "serviço público de competência da União", conferindo a execução, direta ou indiretamente, à Caixa Econômica Federal (art. $1^{\circ}$ ). Define o que venham a ser "bingo permanente" (art. $2^{\circ}, \S 1^{\circ}$ ) e "bingo eventual" (art. $2^{\circ}, \S 2^{\circ}$ ). À Caixa Federal coube a fiscalização dos jogos de bingo (art. 15) - fato importante e nada explorado na CPI —, devendo comunicar as irregularidades de imediato ao Ministério Público (art. 16).

Note-se que é a União, novamente, apoderando-se, via Decreto, do monopólio do jogo, ao menos na modalidade de "bingo". Não é difícil ver que poderiam ser

depois pertinentes críticas. Segue-se menção do autor ao fato de que "bingo é jogo, mas não é desporto, e pior, é jogo de azar, gerador de escândalos e corrupçōes na 'comercialização' $e$ 'mercantilização' das autorizaçōes outorgadas pelo poder público, tão alardeadas pela mídia $e$ objeto de ações do Ministério Público Federal" (p. 219), em evidente alusão à ação de improbidade contra o Ministro Rafael Grecca e outros mencionada nesta promoção.

14 Sobre isso, ver parecer de MARTINS, Ives Gandra da Silva. Inteligência dos arts. 71, 73, 74 e 78 do Projeto de Lei $n^{\circ} 1.159 / 95$ (Lei Pelé) - possibilidade de exploração dos jogos etetrônicos nas ante-salas de bingo - o direito adquirido da Lei n. 8.672/93 (Lei Zico) parecer. Revista Trimestral de Jurisprudência dos Estados, v. 165, pp. 111-122, jul./ago. 1998.

15 Anote-se, no entanto, o aplauso de MELO FILHO, (nota 3), p. 220 , ao artigo $2^{\circ}$ da Lei $9.981 / 2000$, que diz ser "insuscetível de críticas". 
objetados, ao Decreto 3.659/2000, análogos argumentos aos que CAIO TÁCITO opôs ao Decreto 204/1967, agora com muito mais razão, sob a nova ordem constitucionais. ${ }^{16}$

Vê-se que não é preciso muito esforço para aceitarmos o que venho chamando de "caos normativo".

A quem quer entender a temática, é indispensável que compreenda isto: os "jogos de azar" sempre existiram e foram fonte da riqueza de poucos e da esperança de muitos. O Estado, percebendo isso, quis regular e, mormente, tributar, juridicizando, a relação fática existente entre o sujeito-arrecadador e o sujeito-apostador, assim auferindo recursos. Estabeleceu regras ao funcionamento do jogo, disse que jogos eram permitidos e, fundamentalmente, avocou a si o exclusivo poder de regular, autorizar, conceder, controlar e fiscalizar o jogo. Fora do que o Estado permite, o jogo é ilícito. Acima de tudo, quis o Estado, por tributos, angariar recursos.

Já se falou dos plúrimos interesses envolvidos no tema. Todas as atividades que o Estado se dispôs a realizar acabaram refletindo justamente essa pluralidade de fatores, e o resultado disso, seja faticamente, seja normativamente considerando, não são dos mais alentadores.

É de clareza solar que o Estado exerceu as tarefas que avocara não muito ordenadamente, e frequientemente o fez com regras pouco claras, ou, quando se tratava de fiscalizar, fê-lo, na maioria das vezes, com leniência, incompetência, conivência ou despreparo. Se somarmos a isso os desmandos e a corrupção que sempre permeou - infelizmente - a esfera pública de nosso país, vemos com não menor clareza que o resultado não seria outro senão o hoje existente: caos fático normativo, com reflexo social e, última instância, como esperado, jurisprudencial.

Vem dessa situação a possibilidade - aqui já bem previsível — da existência de uma pluralidade de ordenamentos jurídicos dos diversos Estados sobre a matéria, no que toca à exploração de loterias ou bingos.

No Estado do Rio de Janeiro, hoje, exploram-se, com amparo do Poder Judiciário, que nada mais faz do que interpretar esse caos normativo e tenta - muitas vezes em vão - dar-lhe sentido, bingos de todas as espécies. Nos Estados do Paraná e Santa Catarina ocorre algo semelhante - conforme informação prestada pelo Sr. Governador do Estado em resposta via Of. Gab. n ${ }^{\circ}$ 03/02, recebido em 07.01.2002 por este MPE, com documentação pertinente.

"No nosso Estado se passa algo parecido, no que toca à desorganização, no âmbito jurisprudencial. Recentemente o Tribunal de Justiça gaúcho foi chamado muitas vezes a pronunciar-se sobre a possibilidade de utilização de máquinas eletrônicas, bem como sobre diversas apreensões das referidas máquinas pela autoridade policial".

A leitura dos vários acórdãos, raramente unânimes, deixa transparecer uma quase impossibilidade de consenso razoável ${ }^{17}$, até mesmo em relação à competência

16 Ver, sobre isso, o artigo de SUNDFELD, Carlos Ari. Loterias Estaduais na Constituição de 1988. Revista de Direito Público, v. 91, pp. 95-102, jul./set. 1989, sustentando que o parecer de Caio Tácito mais se justificaria sob a égide da $\mathrm{CF} / 88$.

17 Conferir MS 599445004, $1^{\circ}$ Grupo Cível, j. 29.10.1999, rel. Desa. Liselena Ribeiro: MS 699057865, 5a Câm. Criminal, j. 16.06.1999, rel. Des. Paulo Moacir Vieira; MS 70000651083, $2^{\circ}$ 
para tratar da matéria (se de alçada cível ou criminal ${ }^{18}$ ), justamente em função do intrínseco aspecto criminal que advém - ou pode advir — da liberação do uso de máquinas eletrônicas de bingo.

O que se passou no Estado do Rio Grande do Sul por meio dos famigerados Decretos e Instruções Normativas, objeto de indiciamento pelo RF-CPI, foi em verdade uma tentativa de regulamentação do caos, como se verá adiante, com vistas também à arrecadação de receita.

Vale, antes de passarmos ao próximo item, a citação - posto que longa - do debate franco havido na CPI em 11.06.2001 entre o Deputado Ronaldo Zülke (PT) e o Dr. Marco Antônio Lopes, Superintendente de Loterias e Jogos da Caixa Econômica Federal, sobre a "guerra" entre União e Estados na tentativa de angariar recursos do jogo:

O SR. RONALDO ZÜLKE - Dr. Marco Antônio, o Senhor quando fez aqui a exposição, utilizando-se dos recursos visuais, eu pude observar que o Senhor fez referência a dois decretos que versam de 67 e 69, data da assinaturas desses decretos. É bom que se diga, nesse período nós vivíamos no País, lamentavelmente um regime discricionário e que tinha como política a centralização da receita, dos recursos na União. Então, esses decretos que têm essa origem, segundo a sua apresentação, estabeleceram de que sobre esse tema de jogos, loterias, enfim, é de competência exclusiva da União, enfim estabelecer. [fim]

No entanto, a Constituição da República de 88 , que, entre outras questões, modificou consideravelmente a nossa legislação, a meu juízo em muitos aspectos significou um avanço, diz no seu art. 22: Compete privativamente à União legislar sobre: inciso XX - sistemas de consórcios e sorteios. Deve ser nisso que o Senhor também está-se referindo, quando sustenta que é de competência exclusiva da União. [fim]

Mais adiante, na Constituição também diz no art. 195, da seguridade social: a seguridade social será financiada por toda a sociedade, de forma direta e indireta, nos termos da lei, mediante recursos provenientes dos orçamentos da União, dos Estados, do Distrito Federal e dos Municípios, e das (...) contribuições sociais. Inciso III - sobre a receita de concursos de prognósticos. Parece-me que concursos de prognósticos é mais claro do que consórcios e sorteios. [fim]

Grupo Criminal, j. 09.03.2001, rel. Des. Constantino L. de Azevedo, vencido Des. Gaspar Batista; MS 70000801795, $1^{\circ}$ Grupo Cível, j. 02.06.2000, Rel. Desa. Liselena Ribeiro, vencidos Des. Genero Borges, Roque Wolkweiss e Francisco Moesch; MS 70000823633, $1^{\circ}$ Grupo Cível, j.02.06.2000, rel. Des. Irineu Mariani, vencidos Des. Genaro Borges, Roque Vollcweiss e Francisco Moesch (idêntica situação do MS 70000704320); MS 70000656751, $1^{\circ}$ Grupo Cível, j. 02.06.2000, rel. Des. Marco Aurélio Heinz, vencidos os Des. Genaro Borges, Roque Volkweiss e Francisco Moesch; MS 70000668913, Câm. Férias Criminal, j. 02-032000, rel. Des. Vasco Della Giustina, unânime; AC 70000025650, 1 Câm. Especial Cível, j. 11.04.2000, rel. Des. Roque Wolkweiss, unânime.

18 Ver MS 70000633107, $1^{\circ}$ Grupo Cível, j. 02.06.2000, redator Des. Irineu Mariani, rel. vencido Des. Francisco Moesch; MS 70000659268, $1^{\circ}$ Grupo Cível, j. 15.09.2000, redator Des. Arno Werlang, rel. vencido Des. Marco Aurélio Heinz. 
Também, sobre esse mesmo tema, há uma lei de $n^{\circ} 8.212$, de 91 , que também trata sobre Lei Orgânica de Seguridade Social e, que também diz que constitui a receita da seguridade social, consideram-se concurso de prognósticos todos e quaisquer concursos de sorteio de números, loterias, apostas, inclusive as realizadas em reuniões hípicas, nos âmbitos federal e estadual, do Distrito Federal e Municipal. Portanto, reforça aquilo que está estabelecido no art. 195, da Constituição. [fim]

Há aí uma controvérsia: alguns interpretam que é competência exclusiva da União; já outros interpretam que os Estados e os Municípios também podem legislar sobre isso. É possível que, baseado nisso, o Rio de Janeiro tenha sustentado essa oposição e, portanto, tenha obtido decisão judicial favorável a que o Rio de Janeiro legisle sobre isso. Por que o Rio Grande do Sul não poderia legislar sobre isso? Por que o Rio Grande do Sul já legislou e, portanto, está em condições de atuar nessa área, por que, na sua opinião, para nós é diferente? [fim]

OSR. MARCO ANTÔNIO LOPES - Na verdade, a diferença reside na origem. $\mathrm{O}$ que existe no Rio de Janeiro tem origem numa demanda judicial, e não numa decisão gerencial ou corporativa da Caixa Econômica Federal. Então, não houve uma decisão nossa dizendo: não, para o Rio de Janeiro vai ser assim, para o Rio Grande do Sul vai ser diferente, em detrimento do Rio Grande do Sul. Esse é o primeiro aspecto que eu queria ressaltar. [fim]

$\mathrm{Na}$ verdade, o que aconteceu no Rio de Janeiro é uma imposição, ainda que em caráter liminar, mas oriunda de uma decisão judicial, contra a qual nós já recorremos. Correto? [fim]

Em São Paulo houve uma ação semelhante na Justiça Federal. Nós perdemos em caráter liminar e, há cerca de três semanas, conseguimos cassar a liminar e passamos a exercer a fiscalização. Quando me refiro a isso, estou me referindo aos jogos de bingo. Não estamos no campo das loterias ou no campo das promoções, o que, para o entendimento comum, às vezes, pode parecer um pouco confuso. Então, é com relação a bingos. [fim]

Com relação a bingos, no Rio Grande do Sul, o processo transcorreu normalmente dentre aquelas casas que já funcionavam. Diante da pergunta do Deputado Vieira da Cunha, se o bingo, previsto na legislação estadual, era reconhecido pela Caixa, tal qual a visão que nós temos com relação a toda e qualquer tentativa semelhante por qualquer Estado, é de não reconhecimento desse bingo permanente, que vem a ser administrado pela loteria estadual. Então, aí não há diferença de tratamento, correto? [fim]

OSR. RONALDO ZÜLKE - A não ser que pague um percentual para a Caixa? [fim]

O SR. MARCO ANTÔNIO LOPES - Não, o percentual definido pela Caixa está na lei, e ele não distingue a origem dessa atividade, ou melhor, ele delimita que essa atividade só pode ser explorada mediante regularização da Caixa. Vale dizer: essas entidades não pagam a Caixa para poder explorar o bingo. Depois de poderem 
explorar o bingo e regularizadas perante a lei, e conforme a lei, elas pagarão uma taxa, uma tarifa, uma comissão para a Caixa, para que nós tenhamos a cobertura dos nossos custos operacionais, inclusive incluindo a Polícia Federal. [fim]

O SR. RONALDO ZÜLKE - O caso de Minas Gerais não tem nenhum problema porque, em Minas Gerais, eles pagam uma taxa, um pedágio para a Caixa. [fim]

O SR. MARCO ANTÔNIO LOPES - Vamos esclarecer. Nós falamos de bingo. Essa sua pergunta com relação a Minas teria qual direção? Jogos, loterias? [fim]

OSR. RONALDO ZÜLKE - Esses jogos que, no seu entendimento, os Estados não têm como legislar sobre eles. [fim]

O SR. MARCO ANTÔNIO LOPES - Exatamente, nós padecemos aí de um outro problema: há uma infinidade de jogos que se estabelecem no mercado. Alguns se confundem, como o bingo eventual, o bingo permanente ou promoções comerciais. [fim]

Ato contínuo, eles têm buscado abrigo na loteria estadual e, em obtendo essa cobertura por parte das loterias estaduais, adquirem a condição de legalidade. Aquilo que não era legal, no momento em que estiver vinculado a uma loteria estadual, estará legalizado. [fim]

\section{O SR. RONALDO ZÜLKE - Como é o nosso caso? [fim]}

O SR. MARCO ANTÔNIO LOPES - Sim. Esse é o caso específico, com duas modalidades ocorrentes no mercado local. Também no caso de Minas, nós estamos revendo a situação. [fim]

Então, a questão que eu queria deixar bem claro: não se restringe a uma vontade corporativa, que estaria limitada a uma estratégia de mercado, ou não, da Caixa, ou a uma vontade pontual dos seus administradores. Ela decorre desse entendimento legal, e é a partir dele que nós estaremos direcionando nossas ações. [fim]

Estamos revendo, também, todas essas modalidades que já estavam em vigor, e, aí, nesse sentido, a gente se depara com essas dificuldades, dificuldade de caráter administrativo, jurídico-legal e, até, de diversidade de interpretação. [fim]

Realmente, o Senhor tem razão quando suscita eventuais pontos conflitantes na legislação, e nós até admitimos que eles possam ocorrer, só que nós, como administradores de jogos, como entidade que foi excepcionalizada pelo Código Penal, nós não podemos ter dúvida; nós temos que ter um comportamento e nós temos que ter uma diretriz. [fim]

Onde é que nós buscamos nossa diretriz? Na lei. Imagine o Senhor se viéssemos nós aqui e contribuíssemos para a dúvida: Não, a Caixa não tem um posicionamento, nós não sabemos se são os 204 , se é os 22 , se é os 195. Não: nós temos um posicionamento. A partir dele, com contra-argumentação e tudo mais, nós vamos tentar estabelecer, no plano nacional, um entendimento que seja uniforme. A gente sabe que é difícil, mas... [fim] 
O SR. RONALDO ZÜLKE - Perfeito. Eu entendo perfeitamente a posição da Caixa. Acho que ela está cumprindo o seu papel, ela busca na legislação algo que sustente a sua política de arrecadar mais inclusive. Acho que isso é lógico, normal que seja assim. [fim]

O SR. MARCO ANTÔNIO LOPES - Só farei uma correção - me permita necessariamente, não arrecada mais, mas arrecada bem, com transparência e dentro da legalidade. [fim]

OSR. RONALDO ZÜLKE - É o que os Estados também podem, perfeitamente, buscar. [fim]

O SR. MARCO ANTÔNIO LOPES - Sem dúvida nenhuma. [fim]

O SR. RONALDO ZÜLKE - Portanto, aí há, na verdade, uma disputa do ponto de vista financeiro. A Caixa tem interesses em fiscalizar e atuar nessa área porque tem o interesse econômico-financeiro por trás disso. [fim]

A propósito, o Senhor poderia nos brindar, com números, o que que a Caixa arrecada hoje com esses jogos? [fim]

O SR. MARCO ANTONNIO LOPES - Assim, Deputado, para não parecer um pecado, assim como o Estado, também, tem interesse econômico. [fim]

O SR. RONALDO ZÜLKE - Claro, perfeitamente legítimo. Assim como é legítimo para a Caixa, também é legítimo para o Estado, na minha opinião. [fim]

O SR. MARCO ANTÔNIO LOPES - Exatamente. [fim]

$O S R$. RONALDO ZÜLKE - E, aí, cada um busca a sua interpretação jurídica. No Rio de Janeiro, eles já ganharam... [fim]

O SR. MARCO ANTÔNIO LOPES - Só para não parecer que o pecado está só do nosso lado. [fim]

O SR. RONALDO ZÜLKE - Não, claro, não, sem dúvida. [fim]

No Rio de Janeiro, eles já ganharam uma ação judicial e estão arrecadando. O Estado de Minas, eles têm um acordo com a Caixa e arrecada e repassam percentual para a Caixa. [fim]

O SR. MARCO ANTÔNIO LOPES - Paga comissão aos lotéricos. [fim]

O SR. RONALDO ZÜLKE - Paga uma comissão. [fim]

O SR. MARCO ANTÔNIO LOPES - Mas, aí, é o que se diz: é um acordo negocial. Nada impede que se venha a ter um acordo negocial e mercadológico com 
as loterias estaduais. Nós não chegamos nesse ponto. Esse ponto seria uma convivência dentro de um negócio normal, dentro dessa atividade. Não há nenhum óbice, não há nenhuma contrariedade da Caixa com relação a isso, até porque nós entendemos que a dimensão de uma loteria estadual, ela é bem diferente da dimensão da Loteria Federal, ou das loterias que nós administramos. [fim]

Eu até lhe diria que o poder de fogo, a tecnologia e a capacidade de rede que nós temos, ninguém tem no País. Então, nós não vamos sobre o enfoque concorrencial puro. [fim]

O SR. RONALDO ZÜLKE - Desse ponto de vista, então, é absolutamente legítimo que o Estado busque estabelecer em lei um regramento sobre isso, para atuar nisso, como, aliás, nós fizemos aqui, o que, segundo eu estou informado, foi de fundamental importância para que o Rio de Janeiro obtivesse a decisão favorável na Justiça para sustentar a sua posiçĩo. [fim]

O SR. MARCO ANTÔNIO LOPES - Não, aí não há uma conexão, até porque os fatos não ocorreram simultaneamente, ou este ou aquele em decorrência deste. $O$ Rio de Janeiro foi uma situação isolada com relação a bingos. [fim]

$O S R$. RONALDO ZÜLKE - Não, mas a informação que temos é de que eles tenham ganho na Justiça, exatamente por que tem uma lei estadual. [fim]

O SR. MARCO ANTÔNIO LOPES - ...loteria estadual, inclusive, no Rio de Janeiro há uma outra particularidade. Inclusive, nas casas lotéricas, também por decisão, em caráter liminar da Justiça Federal, a Caixa não pode fiscalizar nem as próprias loterias que ela administra. Correto, então, é uma situação totalmente diferenciada e diferente. [fim]

O SR. RONALDO ZÜLKE - Eu me daria por satisfeito, Sr. Presidente, se o Dr. Marco nos brindasse com um número de quanto a Caixa arrecada nesta parte de jogos, bingos, enfim, e como é que a Caixa procede a fiscalização, os números totais. [fim]

O SR. MARCO ANTÔNIO LOPES - Mas eu posso lhe dizer, isso está no orçamento da Caixa. Nós esperamos ter uma receita, neste ano, de 281 milhões, administrando loterias, jogos e receita, certo, Deputado? [fim] [fim]

O SR. RONALDO ZÜLKE - Vamos dividir um pouco isso com os Estados.

O SR. MARCO ANTÔNIO LOPES - Pois é, desde que os Estados nos ajudem a pagar as despesas. Não teria problema nenhum. [fim] (grifei)

Numa palavra: não parece haver dúvidas de que os Estados querem, em verdade, "parte do bolo", e que a União quer "o bolo inteiro".

Em função das já mencionadas divergências doutrinárias e jurisprudenciais é que a Procuradoria do Estado do RS, via Informação 53/100 - PDPE, subscrita pelo 
DD. Procurador do Estado Bruno de Castro Winkler, encaminhada com os Ofícios Gab. 03/02 do DD. Governador do Estado e 052/02 pelo DD. Secretário da Fazenda, entendeu que "o Estado do Rio Grande do Sul detém competência para explorar direta ou indiretamente, regular, fiscalizar, autorizar ou credenciar os serviços de loterias ou atividades lotéricas no seu território, inclusive nas modalidades de jogo de bingo e outras existentes, como aquelas referidas no art. $8^{\circ}$ do projeto de lei 'sub examine', ou mesmo que venham ser criadas, observados os limites de sua competência".

Uma tal orientação da Procuradoria do Estado do RS não é nova, aliás. O DD. Secretário da Fazenda remeteu, com o mencionado Of. 052/02, cópia do Parecer $\mathrm{n}^{\circ}$ 7324, datado de 18.11.1987, lavrado pela Procuradora Sílvia Laporta e acolhido, por unanimidade, pelo Conselho Superior da Procuradoria-Geral do Estado. O parecer respondia à consulta, feita pelo então subchefe da Casa Civil àquela Procuradoria, acerca de dois pontos: a) a possibilidade de a matéria de emissão de bilhetes lotéricos ser objeto de regulação em nível estadual; e b) se a matéria poderia ser objeto de disciplina pelo Poder Executivo. O Executivo, à época, pretendia, por Decreto, regulamentar a emissão de bilhetes lotéricos até o limite de 100.000 (cem mil) por extração, pela Caixa Econômica Estadual (CEE).

Após reiteradas menções ao também aqui amiúde citado parecer do Prof. CAIO TÁCITO, concluiu a eminente Procuradora do Estado por dar resposta afirmativa a ambas as questões: podia haver regulamentação em nível estadual, e isso poderia ser feito por Decreto.

Interessante notar que a minuta do Decreto então analisado era acompanhada de Exposição de Motivos apresentada pelo Diretor da CEE, que dizia que o objetivo perseguido seria "tomar rentável e competitiva a Loteria Estadual, de sorte que os recursos que hoje se evadem de nosso Estado, para a União, possam aqui permanecer para o atendimento das necessidades locais".

O Parecer 7324 da PGE também traz outros dados históricos importantes na autêntica "guerra fiscal": refere que a Associação Brasileira de Loterias Estaduais propôs a inclusão de parágrafo único do art. 53 do Anteprojeto da $C F / 88$, no qual previa expressamente ser da competência dos Estados a legislação regulamentadora da loteria estadual, em texto do Senador Alfredo Campos.

Por outro lado, e ainda nesta temática, com o já aludido Of. Gab. 03/02 do DD. Governador do Estado foram remetidas cópias dos pareceres 10.149 e 11.321 da PGE, mencionados com frequiência pelo DD. Relator da CPI - e que também não acompanharam os documentos oriundos da CPI - como sendo reveladores de opinião da PGE em sentido diverso, isto é, de que não era possível a regulamentação da matéria via Decretos. No entanto, a conclusão que se tira facilmente da leitura dos pareceres é outra, bem diversa daquela insculpida no RF-CPI, data venia.

O primeiro parecer (10.149), datado de 27.06.1994 e da lavra dos Procuradores do Estado César Santolim e Raquel Schmiedel, aprovado pelo então DD. Procurador-Geral do Estado Sr. Carlos do Amaral Terres, foi exarado sob outra realidade normativa (Lei Zico) e respondia à consulta do DD. Secretário da Fazenda sobre a possibilidade de o Sport Club Internacional organizar sorteio para angariar fundos 
para o desenvolvimento do desporto, em modalidade similar à loteria numérica. $O$ parecer 10.149 entendeu que a modalidade de sorteio pretendida não se enquadrava dentre as autorizadas pela Lei Zico, mas somente pelo Decreto Federal 981/193, que a regulamentou e, no caso, foi além da lei, extrapolando limites. O Sport Club Internacional, então, não poderia ser autorizado, sob pena de violar a lei (inclusive contravencional), a praticar o sorteio pretendido. Concluiu o parecer que deveria o órgão consulente expedir Instrução Normativa normatizando a autorização para a realização de sorteios, além de providenciar na elaboração de projeto de lei instituindo taxas em face da realização de serviços públicos e pelo exercício do poder de polícia.

O segundo parecer $(11,321)$, da lavra do Procurador Gabriel Fadel, aprovado pela Procuradora-Geral Dra. Eunice Nequete Machado em 28.08.1996, responde à consulta sobre a existência, à época, de restrições legais à exploração comercial, no Estado, das máquinas eletrônicas TURF GAME. A conclusão é que tais máquinas não estavam ao abrigo da Lei Federal 7.291/84 e constituíam jogo de azar. Só. O parecer nada conclui quanto ao fato de estarem ou não tais máquinas ao abrigo da Lei Zico (então vigente) e do Decreto Federal 981/93.

Vai daí que tem razão a Procuradoria-Geral do Estado, na sua Informação 01/02-GAB, da lavra do Procurador Ricardo Antônio Lucas Camargo e aprovada em 04.01.2002 pelo Procurador-Geral Paulo Peretti Torelly, encaminhada juntamente com o Of. Gab. 03/02 do DD. Governador do Estado, acerca da impropriedade dos referidos pareceres para os fins que se propuseram no raciocínio do RF-CPI.

A normatização do Estado, via Decretos e Instruções Normativas, seguiu, pois, orientação jurídica da Procuradoria-Geral do Estado, que já vinha, aliás, de gestões anteriores e obedecia ao alto nível dos pareceres dos Procuradores do Estado do RS. Pode-se até discutir seu conteúdo, mas partir de uma suposta inabalável certeza acerca da incompetência do Estado do RS para regular a matéria a fim de tingir de ímprobos os atos administrativos normativos é dar passo além do permitido pelo Direito vigente, data venia, como será tratado adiante. Antes, deve-se ressaltar o exato teor dos mencionados atos administrativos normativos.

(iii) A legislação estadual sobre "jogos de azar" - Os Decretos Estaduais/RS 40.593, 40.635 e 40.765. e as Instruções Normativas 01 e 02/2001 - tentativa de normatização do "bingo" e delimitação do objeto desta análise

Lembra RUY CIRNE LIMA que a Constituição do RS de 14 de julho de 1891, no art. 72, § 18, dispunha: “ficam abolidas as loterias, não sendo lícito ao Estado converter o vicio em fonte de receita". Mas, já em 30 de janeiro de 1893 - continua o mestre - o Estado firmava o contrato para a celebração de loteria, depois rescindido por Decreto $\mathrm{n}^{\circ} 50$, de 2 de dezembro de $1895^{19}$. 
Deixando de lado legislações mais antigas e saltando ao séc. XX, em 15 de janeiro de 1947, via Decreto-Lei 1.350, era criado o Departamento de Loteria do Estado, extinto, depois, em 16 de julho de 1975, pela Lei 6.893, que, além de definir a loteria como "serviço público" e conferir à Caixa Econômica Estadual a exclusividade da exploração do serviço (art. $1^{\circ}$ ), transfere o patrimônio daquele Departamento a esta Caixa Econômica (art. $2^{\circ}$ ), reestruturando, no âmbito da Caixa, os cargos e servidores daquele Departamento (arts. $3^{\circ}$ a $7^{\circ}$ ), regulando a receita oriunda do serviço (art. $9^{\circ}$ ) e revogando expressamente o mencionado Decreto 1.350/1947 e a Lei 5.108, de 26.11.1965 (art. 11).

No mesmo ano de 1975 , a Lei 6.953 , de 29 de dezembro, dispôs sobre a aplicação da receita proveniente da exploração do serviço de loterias pelo Estado, estabelecendo percentuais da renda líquida resultante da venda dos bilhetes (art. $1^{\circ}$ ). Esta distribuição da renda foi alterada em 15 de janeiro de 1998 pela Lei Estadual 11.082 $\left(\text { art. } 2^{\circ}\right)^{20}$.

O Decreto Estadual 33.531, de 16 de maio de 1990, instituiu, no âmbito da Caixa Econômica Estadual, a "loteria instantânea, com bilhetes de resultados imediatos, com distribuição de prêmios ao detentor do bilhete premiado" (art. $1^{\circ}$ ), atribuindo ao Conselho Administrativo da Caixa o poder de regulamentar a nova modalidade lotérica (art. $3^{\circ}$ ).

Os diplomas doravante comentados são de extrema relevância. A Lei 10.356, de 10 de janeiro de 1995, dispõe sobre a estrutura organizacional da Administração Direta. No art. $8^{\circ}$, inc. II, diz com as competências da Secretaria da Fazenda. O Decreto 37.297, de 13 de março de 1997, regula a estrutura básica da Secretaria da Fazenda (art. $1^{\circ}$ ), dispondo suas competências (art. $2^{\circ}$ ) e estruturando os órgãos internos (art. $3^{\circ}$ ). A Lei 11.561, de 27.12.2000, no seu anexo VII, fixa percentuais de taxas de serviços diversos (no caso, taxa para o serviço de loterias), alterando a Lei Estadual 8.109, de 19.12.95. O Decreto 40.593, de 16 de janeiro de 2001, acresce àquelas competências um inciso XII ("administração do serviço público de loterias do Estado") e, a estes órgãos, a Loteria do Estado do Rio Grande do Sul LOTERGS, depois regulando minudentemente as atribuições da LOTERGS e instituindo diversas modalidades lotéricas (art. $2^{\circ}$ ), dentre elas a videoloteria (inc. II). $\mathrm{O}$ Decreto 40.635, de 13 de fevereiro de 2001, altera minimamente o Dec. 40.593, e o Dec. 40.765 , de 18 de maio de 2001, revoga expressamente o inc. II (videoloteria).

Porque imprescindível, faz-se agora digressão sobre a modalidade de bingo que causou toda a prọblemática em questão e que gerou a ação de improbidade do MPF,

20 Durante a CPI, o Deputado Germano Bonow, quando do depoimento do Sr. José Vicente Brizola, fez alusão à Lei 11.082. Palavras do ilustre Deputado, inquirindơ a testemunha: "Lhe faço essa pergunta e espero, até, que se o Senhor me fizesse a gentileza de, quando esse documento estiver pronto, eu gostaria que viesse especificado o que determina a legislação, a Lei $n^{\circ} 11.082 / 98$, que fála na questão da irmandade da Santa Casa de Porto Alegre, quanto ela recebeu; quais são as entidades do esporte amador que receberam; o Crédito Educativo, se foi distribuído; as santas casas e os hospitais do interior, da mesma forma as atividades de promoção cultural e os hospitais mantidos por entidades caritativas. Eu gostaria que o Senhor nos assegurasse esses dados, que para mim são dados importantes." 
que, de sua vez, municiou o MJDH a fazer a denúncia que culminou com o indiciamento ora analisado: as videoloterias, ou máquinas caça-níqueis, ou "bingos eletrônicos".

E é imprescindível a delimitação, porque se ventilou inúmeras eventuais irregularidades na CPI quanto aos "jogos de azar". Aquela que deve ser focada é a referente aos "bingos eletrônicos", máquinas caça-níqueis ou videoloterias, porque é essa modalidade de "jogo de azar" que foi - e efetivamente é - proibida pela Lei Pelé (e hoje pelo Decreto Federal 3.659/2000), que só admite duas espécies de bingo: o permanente e o eventual.

É certo que a Lei Zico criou, com a vaga expressão "bingos ou similares" do art. 57, grande confusão, problema que foi, contudo, desfeito pelos já mencionados artigos 73 e 74 da Lei Pelée ${ }^{21}$. A posição que me parece mais razoável, hoje, é a de que os videobingos (ou videoloterias), as máquinas caça-níqueis, enfim, são proibidas, ou ao menos não têm sua utilização autorizada no país ${ }^{22}$. Anote-se aqui que houve várias apreensões pela Polícia Civil deste Estado, de tais máquinas, algumas das quais tidas por ilegais pelo Poder Judiciário, tudo a confirmar o que venho denominando de "caos normativo".

Tentando clarear a temática, resuma-se: o problema de normatizar o "jogo de azar" sempre existiu. Desde 1941 é proibido o "jogo de azar", via LCP (ou, para uns, Dec-lei 6.259/44). O Estado, no entanto, passou a explorá-lo, pela União e pelos Estados membros, em sucessivas normativas, muitas delas conflitantes e reveladoras, paulatinamente, da intenção de cada esfera de angariar recursos com o "jogo". Loterias estaduais e federais foram criadas, em regra sob responsabilidades das respectivas Caixas Econômicas.

De seu turno, o jogo de bingo, com a informática, realidade nova, criou, além do bingo "tradicional", um bingo "eletrônico". Nada mais que uma modalidade cibernética e atualizada de fazer da alea esperança. Sem que os problemas dos jogos "tradicionais" tenham sido resolvidos, e ainda não superadas as querelas sobre competência para normatizar, legitimidade do Estado para punir o jogo, nocividade, deste etc., e como a nova realidade dos "bingos eletrônicos", que carrega consigo além das mazelas que o jogo "tradicional" sempre trouxe, outros problemas decorrentes da modernidade, o Estado-legislador, que sempre corre atrás dos fatos, na busca incessante de regulá-los, viu-se premido pela necessidade de normatizar essa velha-nova atividade. Por isso a evolução legislativa, que nasceu capenga e falha, cresceu cheia de imperfeições, tal qual colcha de retalhos.

21 Ver item (ii) deste parecer.

22 Más note-se que, a despeito da clareza da Lei Pelé, CELSO BASTOS entendeu lícita a atividade dos bingos eletrônicos - ver BASTOS, (nota 5), p. 78. O autor apresenta raciocínio tortuoso, data venia quando afirma, ao comentar o art. 73 da Lei Pelé ("É proibida a instalação de qualquer tipo de máquina de jogo de azar ou de diversões eletrônicas nas salas de bingo"): "Ora, a contrario sensu, o que se extrai do dispositivo é a licitude da instalação de qualquer tipo de máquina de jogo de azar ou de diversões eletrônicas desde que não ocorra nas salas de bingo." (p. 79). 
É preciso não perder de vista, portanto, que os atos administrativos normativos que se está a analisar, sob seu aspecto de improbidade, devem ser nesse contexto interpretados.

(iv) Sobre a (i)legialidade dos "jogos de azar" - Falta do elemento subjetivo da improbidade na edição de atos administrativos normativos

Para chegar à conclusão de que houve improbidade administrativa na normatização dos "jogos de azar", o RF-CPI parte da premissa, adotada em recomendação do MPF à LOTERGS, dirigida em 22.02.2001 ao Sr. José Vicente Brizola, então Diretor da LOTERGS, e em parecer deste Ministério Público Estadual proferido no expediente administrativo $n^{\circ}$ 008336-09.00/98-7, de que a competência a legislar sobre a matéria é da União Federal, forte o dito no art. 22, $\mathrm{XX}$, da $\mathrm{CF} / 88$ ("Compete privativamente à União legislar sobre sistemas de consórcios e sorteios").

Inicialmente, diga-se, embora evidente, que não é o fato de haver eventual e simples invasão de competência legislativa que tornaria ímprobo qualquer ato, fato que reclamaria, em princípio, ação de inconstitucionalidade/ilegalidade da norma, e nada mais. Não se diga, no entanto, que não seja possível o cometimento de improbidade administrativa via edição de decretos ou instruções normativas. Porque para efeitos de improbidade administrativa é necessário considerar o "conceito" de ato administrativo no seu sentido amplo, e não no seu sentido estrito ${ }^{23}$. Os Decretos e as Instruções Normativas são, sim, passíveis de veicular, enquanto atos administrativos normativos ${ }^{24}$, improbidade administrativa.

Mas é necessário, para a configuração da improbidade do art. 11 da LIA, que tenha havido, na edição dos famigerados Decretos 40.593 e 40.765 e Instruções Normativas 1 e 2/2001 da LOTERGS, desonestidade, má fé (subjetiva), intenção dolosa de beneficiar este ou aquele, enfim, vontade de agir com impessoalidade, editando normas em tese gerais para, em verdade, beneficiar particulares, incorrendo no clássico vício do desvio de finalidade do ato administrativo, o que não está, nem de longe, comprovado, entretanto.

Os Decretos e as Instruções Normativas mencionadas teriam sido editados pelo Governo do Estado, segundo a "denúncia" do MJDH - que acabou "encampada" pela CPI - para tentar legalizar a prática dos "jogos eletrônicos" no Estado, legalização essa que seria, por norma Estadual, impossível, segundo o RF-CPI. E essa legalização teria o intuito de beneficiar determinadas pessoas, supostamente

23 Tomo a noção a BANDEIRA DE MELLO, (nota 9), pp. 330-1. O autor distingue os atos administrativos em sentido amplo, que abrange os atos gerais e abstratos, como regulamentos, instruçōes e muitas resoluçōes, mais os atos convencionais, dos atos administrativos em sentido estrito, que teriam, em comparação com os primeiros, acrescidas as características de concreção e unilateralidade. Não importa aqui se a noçāo de ato administrativo comporta ou nāo uma tal distinção, nem que haja autores que excluem os decretos e regulamentos do âmbito conceitual dos atos administrativos, por sua característica de generalidade, como, v.g., FIGUEIREDO, Lucia Valle. Curso de Direito Administrativo, 5 ed.. São Paulo: Malheiros, 2001, p.157.

24 Segundo a clássica lição de MEIRELLES, (nota 8), pp. 161-4. 
envolvidas em atividades ilícitas, como o "jogo do bicho" e outras "jogatinas", que teriam tido contato com representantes do Governo e quiçá participado da elaboração dos Decretos e das Instruções Normativas.

Essas ilações do RF-CPI, entretanto, têm pouca consistência, data venia, e seriam facilmente desmentidas se fossem examinados com atenção alguns dos documentos que a própria CPI dispunha, se fossem bem aquilatadas as informações colhidas e se tivessem sido feitas outras diligências, como aquela acima mencionada de contato com o MPF.

Explicitem-se os fatos, a começar da decantada premissa segundo a qual somente a União Federal pode editar normas relativas aos "jogos de azar", gênero do qual o "bingo" é espécie e o "bingo eletrônico" é subespécie. Tal premissa não é, nem de longe, ponto pacífico na doutrina nacional, como já se viu.

Com efeito, relembre-se, sem prejuízo dos respeitáveis entendimentos dos colegas do MPF e Estadual consubstanciados na Recomendação e no parecer antes aludidos, haver não menos respeitáveis posições jurídicas contrárias, que advogam tratar-se de matéria melhor encaixada dentro da temática de "concurso de prognósticos" (art. 195, III, da CF/88), de competência residual, e, portanto, dos Estados (art. $25, \S 1^{\circ}, \mathrm{CF} / 88$ ).

Neste sentido, e apenas para mencionar alguns poucos, são os pareceres de CELSO RIBEIRO BASTOS ${ }^{25}$, CARLOS ARI SUNDFELD ${ }^{26}$, LUIZ ROBERTO BARROSO $^{27}$ e ÁLVARO MELO FILHO ${ }^{28}$, todos já aludidos, valendo lembrar que neste passo importa pouco o fato de terem tais pareceres sido exarados antes da vigência da Lei 9.615/98 (Lei Pelé), que, no seu art. 60 (redação dada pela Medida Provisória 1.926, de 22.10.1999), refere que cabe à União credenciar as entidades que pretendem explorar jogos de bingo "permanente e eventual", cabendo ao INDESP autorizar e fiscalizar seu funcionamento. E importa pouco porque se cuida de avaliar tão-somente se, à luz da Constituição Federal, seria possível (constitucional) a edição de normas estaduais acerca da matéria ${ }^{29}$.

Anote-se que o entendimento de que os Estados membros poderiam legislar sobre matéria de "loterias" vem já da Carta Constitucional de 1969. CAIO TÁCITO emitiu parecer, já mencionado, em outubro de 1985 em consulta acerca da constitucionalidade do Projeto de Lei 482/85, de iniciativa do Governador do Estado de São Paulo de então, que restabelecia a Loteria Estadual, sob a denominação de

25 Ver BASTOS, nota 5 supra, pp. 74-89.

26 Ver SUNDFELD, (nota 16) supra.

27 BARROSO, (nota 12).

28 Ver nota 3 supra.

29 Aliás, sob esta perspectiva da constitucionalidade e da repartição de competências, seria também possível questionar se o art. 60 da Lei $9.615 / 98$ não fere a Carta Política ao atribuir à União o exercício monopolístico da exploração das loterias, uma vez que tal matéria não está elencada entre as matérias elencadas no art. $177 \mathrm{da} \mathrm{CF/88,} \mathrm{como} \mathrm{fez} \mathrm{Carlos} \mathrm{Ari} \mathrm{SUDFELD,} \mathrm{(nota} \mathrm{16),} \mathrm{p.} \mathrm{98,} \mathrm{ao}$ tratar do art. $1^{\circ}$ do Dec.-Lei 204/67, que dispôs ser a exploração de loteria um serviço público exclusivo da União. 
"Loteria da Habitação", cuja receita líquida constituiria um Fundo Rotativo Especial, destinado ao financiamento do sistema habitacional popular e da infra-estrutura urbana de apoio. O resultado líquido da exploração da loteria, a Cargo da Caixa Econômica do Estado, seria partilhado, em partes iguais, entre os Municípios e o Estado $^{30}$. O emérito Professor Titular da UERJ concluiu que o Estado de São Paulo poderia livremente criar loteria estadual como um serviço público em seu território.

$O$ artigo de doutrina de CARLOS ARI SUNDFELD antes citado transcreve boa parte do trabalho de CAIO TÁCITO e propõe-se a analisar se a CF/88 inovou na matéria, mormente ante a previsão do art. 22, XX, base do raciocínio do RF-CPI. Concluiu SUNDFELD seria possível, em face da CF/88, ao Estado de São Paulo criar e manter seu próprio serviço de loteria.

Não se está aqui a dizer que as conclusões da recomendação do MPF e do parecer do MPE quanto à impossibilidade de os estados normatizarem a temática das "loterias" são equivocadas. Somente se quer enfatizar que essa não é a única interpretação existente, e que outro entendimento é, também, razoável, e, se assim é, não parece prudente tomar como "flagrantemente inconstitucional", como fez o RF-CPI (fl. 94), a edição do Decreto 40.593, pelo motivo de que não teria " $o$ Estado-Menbro competência para legislar sobre a matéria", sendo digno de nota que a Informação 53/00 da Procuradoria do Estado, em estudo apropriado, o Procurador Bruno de Castro Winkler fez alusão - corretamente - a todos esses aspectos controvertidos. A conclusão do RF-CPI parte, portanto, de uma premissa falsa, qual seja, a da suposta evidência de que os Decretos seriam inconstitucionais.

A este frágil argumento da "flagrante inconstitucionalidade", o RF-CPI disse ainda que teriam sido comprovadas relações entre o Governo do PT com representantes da contravenção, concluindo que " a denúncia formulada pelo MJDH tem procedência, pois restou comprovado o relacionamento entre autoridades do governo gaúcho e os responsáveis pelas modalidades de jogos eletrônicos proibidos".

Não é assim, todavia. De eventuais encontros entre oficiais do Governo com "exploradores de videoloterias" e outros "jogos eletrônicos", que teriam tido prévio conhecimento acerca de instruções normativas expedidas pela LOTERGS, não é possível, sem certa dose de imaginação, concluir que os atos administrativos normativos expedidos pelo Governo tenham tido o condão e o intuito de, desviando-se da finalidade, beneficiar pessoas privadas, como quer o art. 11, I, da LIA, que nada mais é que a positivação, como ato de improbidade, do desvio de poder ${ }^{3 !}$.

Não impressiona os fato de que podem ter tido, os exploradores de "jogos de azar", contato com o representantes do Governo do Estado, e mesmo discutido sobre normas a serem implementadas. Quem quer estabelecer atividade e precisa de autorização ou permissão para fazê-lo naturalmente procura quem deva orientá-los. Se não há normatização, é razoável que o Estado busque subsídios (noutros Estados, inclusive) para fazê-lo, e, desde que o faça com boa fé (subjetiva), nada impede que

30 Ver TÁCITO, nota 5 supra.

31 Com acerto, nesse sentido, MARTINS JÚNIOR, Wallace Paiva. Probidade administrativa. São Paulo: Saraiva, 2001, p. 231. 
busque junto aos destinatários da norma os dados, o que não significa que vá, tão-somente por isso, o Estado agir em dissonância com o princípio da impessoalidade.

E, neste contexto teórico, não se vê, no mundo dos fatos, qualquer ligação promíscua entre os representantes do Governo do Estado, seja Governador, Secretários ou Diretores da LOTERGS, e "representantes de máfias", criminosos ou representantes de "jogos eletrônicos proibidos", a latere de considerações já feitas sobre o suposto ou real caráter ilícito de tais práticas.

Com a licença da comparação, e a fim de cotejar deduções - uma vez que a resposta do Governo ao RF-CPI também deve embasar, por dever dialético, estas linhas -, deve-se dizer que a ilação do RF-CPI aqui analisada é tão inconsistente quanto aquela que os representantes do Governo tentaram tirar do fato de que, por uma contribuição mínima de campanha dada por um Delegado de Polícia ao Digníssimo Deputado Relator da CPI, verba essa referente a jantar beneficente, estaria comprovada sua (dele Relator) vinculação com o "jogo do bicho", uma vez que o referido Delegado seria "advogado de bicheiros". Ambas as inferências são falsos silogismos.

A menos que se aceite, de uma lado e a priori, que todos os representantes de bingos e proprietários de máquinas caça-níqueis são desonestos e criminosos; que todas as conversas que eles mantêm com seus interlocutores visem ao ilícito e à extensão de sua suposta "rede internacional"; e que tenham eles, nessa conversa, um poder de êxito tal que consigam transformar em ação alheia seus anseios, pelo que teria o Governo agido "em obediência" a tais aspirações - e, de outro lado, a menos que se aceite, também a princípio, que qualquer contribuição de campanha, mesmo a compra de ingresso para um jantar, revela ato consciente de patrocínio às causas do beneficiário da verba e de adesão irrestrita aos seus ideais; e que o fato de alguém ser advogado de outrem faz do primeiro cúmplice do segundo, como uma doença contagiante, não é possível chegar às conclusões apresentadas pelo RF-CPI - ou, na comparação, pelas ilações dos representantes do Governo atual para com o DD. Relator da CPI.

Se o Governo do Estado queria regulamentar o "jogo de bingo eletrônico", ou viodeoloteria, e para isso expediu o Decreto 40.593, de 16 de janeiro de 2001, prevendo, no seu art. $2^{\circ}$, II, a possibilidade da modalidade lotérica de videoloteria, a verdade é que tal modalidade jamais foi regulamentada e jamais foi implementada, como aliás foi amplamente explicado pelos seus (ex-) Diretores da LOTERGS ANTÔNIO CARLOS CONTURSI e JOSÉ VICENTE BRIZOLA.

O próprio Decreto 40.593/2001 exigia, para o funcionamento das videoloterias, a regulamentação, via instrução normativa, das novas modalidades lotéricas e concursos de prognósticos (art. $1^{\circ}$, dando nova redação ao art. 16 do Decreto 37.297, de 13.03.1997, no inc. V). Essa regulamentação jamais foi feita, bem ao contrário - $\mathrm{e}$ isto é de suma importância - da atitude tomada pelo INDESP, no Governo Federal, que, em 14 de outubro de 1998, baixou a Portaria $n^{\circ} 104$ e, em 08 de junho de 1999, a Portaria $n^{\circ} 23$, ambas regulamentando a habilitação, a autorização, o controle, a operação e a fiscalização de máquinas eletrônicas programadas para a exploração do jogo do bingo (art. $1^{\circ}$ ), atos administrativos normativos esses que 
foram considerados como atos de improbidade administrativa pelo MPF na já mencionada ação de improbidade administrativa contra o ex-Ministro Rafael Grecca.

Neste Estado, ao contrário do ocorrido no âmbito federal, uma vez que a denúncia do MJDH tinha como esteira justamente a ação do MPF e fazia analogias entre as condutas havidas no plano federal com as havidas no plano gaúcho - , não houve qualquer regulamentação da matéria "jogos eletrônicos", nem por Portaria, nem por Instrução Normativa, nem por qualquer outro ato administrativo normativo. Numa palavra: os atos administrativos que no plano material configuraram a improbidade administrativa no âmbito federal não se deram neste Estado. $O$ que houve aqui foi bem diverso: após a recomendação do MPF, parcialmente acatada pelo Executivo (que discordava, por razões já ditas anteriormente, do entendimento de que somente a União poderia regular a matéria), este resolveu expressamente revogar, via edição do Decreto 40.765, de 18 de maio de 2001 (art. $1^{\circ}$ ), justamente a modalidade de videoloteria que causara problemas no âmbito federal, "para evitar que a referência e essa modalidade pudesse resultar em pedidos judiciais liminares de autorização", conforme explicação oficial do Sr. Secretário da Fazenda (Ofício $052 / 02$, resposta ao quesito 4 ).

Ainda, na esteira desse entender, e provando não haver qualquer atividade administrativa tendente a possibilitar a prática de jogos de videoloteria, o Executivo gaúcho jamais autorizou o funcionamento de máquinas "caça-níqueis" e videoloterias (Ofício 052/02, resposta ao quesito 5). Os Decretos 40.593, 40.635 e 40.765 não foram inspirados nas Portarias Federais tidas como improbas - o que se colhe da resposta do DD. Secretário da Fazenda e se nota da simples leitura e cotejo dos documentos.

Tem-se como provado, portanto, que o Governo do Estado tentou regulamentar o que entendia possível. Ao ser alertado de que poderia haver problemas quanto às videoloterias, retirou dos Decreto 40.593 essa modalidade de bingo. Agiu o Executivo do RS honestamente, portanto, de acordo com seu entendimento. Pode-se até discutir se é necessária lei para tratar da matéria, isto é, pode-se discutir se a criação de órgãos como a LOTERGS e a normatização de loterias dependem de lei (ato normativo), ou se podem ser feitas por decreto (ato administrativo normativo), que parece ter mesmo desbordado de sua necessária característica, para ser válido, de subalternidade à lei, da qual é, ele decreto, vassalo, como já disse alguém. Mas isso é problema de legalidade, desafiando ação própria. Não é, ao menos em princípio e neste caso, problema de improbidade, ou de, como parece mais adequado, desonestidade administrativa.

O ilícito de improbidade é ilícito não-penal. É nova figura normativa entre nós, e a escassa produção dogmática até hoje existente, aqui e alhures, faz com que o intérprete tateie o escuro. Não há certeza acerca dos princípios que norteiam a matéria, que devem ser construídos urgentemente: que filosofia está por trás da sua sanção, quais as balizas da culpabilidade, os parâmetros do tipo e seus elementos, a aplicabilidade do ne bis in idem, e tantas outras.

É digna de nota a proposta dogmática de FÁBIO MEDINA OSÓRIO de se considerar o ilícito de improbidade como parte do Direito Administrativo Sancio- 
nador ${ }^{32}$, que tem também o inconveniente de possuir frágeis fundamentos teóricos. Quanto ao elemento subjetivo configurador do ilícito ímprobo, no entanto, é aceitável tomar como standard interpretativo a vinculação do ato ímprobo a uma certa dose de desonestidade, posição já respaldada noutras oportunidades pelo E. Conselho Superior do MP deste Estado, aderindo à corrente proposta por TÁVORA NIESS e lapidada pelo colega CLÁUDIO ARI MELLO ${ }^{33}$ de que "o legislador pune o administrador desonesto, não o administrador incompetente", registrando-se que essa posição foi sufragada pelo STJ, $1^{\text {a }}$ Turma, Resp. 213.994-MG, Rel. Min. Garcia Vieira, 17.08.1999, v.u., DJU 27-SET.-1999, p.59.

Não é razoável a interpretação literal do art. 11, caput, da LIA de que toda a ilegalidade - admitamos ser ilegal, ou até inconstitucional, a edição de Decretos como os ora analisados - configura improbidade por ofensa ao dever de legalidade. Isso conduziria à improbidade todo e qualquer ato ilegal, o que parece ser rematado absurdo. Claro que há necessidade, para a configuração da improbidade administrativa, de que o elemento subjetivo esteja presente no agir do agente, elemento subjetivo este que a LIA quer, no art. 11, seja o dolo, contentando-se com o agir culposo somente no art. 10.

As condutas atribuídas - faço dedução das genéricas imputações do RF-CPI aos indiciados passam longe da desonestidade. Ainda que sejam responsáveis, à toda evidência, pelos atos administrativos que tomam (e assinam), o ato de assinar Decretos, que até podem ser ilegais, não pode de per si ser tido por ímprobo e desonesto.

Ficam assim de conseguinte afastadas as condutas do DD. Governador do Estado, Sr. OLÍVIO DUTRA, do DD. Vice-Governador, Sr. MIGUEL ROSSETO, dos DD. Chefe e Subchefe da Casa Civil, Srs. FLÁVIO KOUTZII e GUSTAVO MELLO, e do DD. Secretário da Fazenda, Sr. ARNO AUGUSTIN, que se limitaram a apor suas assinaturas nas normativas que, relembro, entendiam legais e tinham motivos para assim pensar e agir. Não há provas de que tenham tais indiciados, em conluio, aprontado decretos e instruções capciosamente para beneficiar terceiros, que com eles estariam mancomunados, numa maquiavélica elaboração para a qual seria preciso construir uma rede de influências nem de longe provada.

Quanto aos Srs. Diretores da LOTERGS, indiciados ANTÔNIO CARLOS CONTURSI e JOSÉ VICENTE BRIZOLA, que teriam - também faço esforço de raciocínio, ante a omissão do RF-CPI - sido os executores ou 'longa manus' ou contato da "armação", tampouco há provas de qualquer participação, por via de conseqüência.

32 MEDINA OSÓRIO, Fábio. Observações a respeito do Princípio Constitucional da Culpabilidade do Direito Administrativo Sancionador. In: SARLET, Ingo Wolfgang (org.). O Direito Público em Tempos de Crise: Estudos em homenagem a Ruy Ruben Ruschel. Porto Alegre: Livraria do Advogado Editora, 1999, pp. 73-74.

33 MELLO, Cláudio Ari. Improbidade Administrativa - Consideraçōes sobre a Lei 8.429/92. in Revista do Ministério Público do Estado do RS, RT, nº 36, p. 176. 
Fique claro que não se está aqui a negar a relação fática que houve e há entre os representantes do Governo - em qualquer Estado da federação - com os exploradores dos jogos de bingo. Evidente que há, e tal contato não foi nunca negado. Dessa realidade fática não se pode, no entanto, num salto indutivo, concluir que essas relações visaram ou visam ao ilícito, data venia.

Numa palavra: não se vê, nos atos administrativos normativos, ato de improbidade. Não foram desonestos os indiciados ao praticar tais atos administrativos. Seguiram pareceres jurídicos. Não há evidências que tenham querido beneficiar qualquer pessoa, bulindo princípios da Administração Pública.

Uma última consideração neste tópico. Há dois projetos de lei dignos de nota neste tocante: um no âmbito federal (Substitutivo ao Projeto de Lei 1.037/1999, do Deputado Federal Gilmar Machado, do PT), propondo a alteração da Lei Pelé, conferindo também aos Estados Membros e ao Distrito Federal a exploração do jogo de bingo (art. $1^{\circ}$, propondo alteração ao art. 60 da Lei Pelé) e incluindo, na definição de bingo permanente, o bingo eletrônico (art. $62, \S 1^{\circ}$ ).

O outro projeto de lei é no âmbito deste Estado (Projeto de lei 315/2001, dos Deputados Estaduais João Luiz Vargas, do PDT, e Frederico Antunes, do PPB), propondo instituir a videoloteria no Estado do Rio Grande do Sul, conferindo à LOTERGS o poder de explorar, credenciado os permissionários, a videoloteria (arts. $1^{\circ}$ e $4^{\circ}$ ), definindo-a (art. $3^{\circ}$, I) e dispondo minudentemente sobre o tema.

\section{Resumo e considerações finais}

O raciocínio levado a efeito talvez pudesse ter sido abreviado, bastando a citação do Ministério Público Federal - inspirador do "denunciante" MJDH - de que não havia ligação do Governo gaúcho com as irregularidades (improbidades) detectadas no Ministério do Desporto e do Turismo, caminho que talvez devesse ter sido, antes, tomado pelo próprio "denunciante".

Porque se entende delicado o assunto, optou-se por uma abordagem mais ampla da temática, tendo sido nesta promoção sustentado o seguinte:

- problema dos "jogos de azar" acompanha a história do País. Desde a LCP, que proíbe ditos jogos, têm sido editadas normas desconexas e pontuais sobre o tema, sendo urgente esforço concentrado, no âmbito dos Estados e da União, ao tratamento do tema.

- A questão da competência para legislar sobre a matéria - se privativa da União ou se subsidiária dos Estados, ou se concorrente - não é pacífica.

- Não houve desonestidade (rectius improbidade) administrativa ao serem editados os Decretos Estaduais 40.593, 40.635 e 40.765 de 2001, ou as Instruções Normativas 01 e 02/2001.

Não foi sustentada a incorreção da recomendação do MFP ao Executivo do Estado, nem afirmada. Não foi sustentada a legalidade do "jogo do bicho", nem da 
exploração das máquinas de videoloterias ou caça-níqueis, nem se adentrou nas minúcias, de resto juridicamente interessantes, acerca de conflitos intertemporais de leis (civis ou penais). Tampouco se advogou a tese, de todo incabivel, de que por atos administrativos normativos não se pode praticar atos de improbidade administrativa.

Quis-se somente, pela menção da razoabilidade de entendimentos vários e discrepantes na matéria, fazer ver que não há possibilidade de se considerar desonesta a normatização de fatos baseados em entendimentos jurídicos plausíveis.

Em suma, se houve conluio na edição dos atos administrativos normativos em comento, isso nem de longe ficou demonstrado nos autos da CPI. Ao contrário, viu-se que o Executivo se baseou em sustentáveis argumentos jurídicos - dos quais até se pode discordar - e regulou a matéria.

Por essas razões promove o Ministério Público pelo ARQUIVAMENTO do presente Expediente $n^{\circ}$ SPI 16564-0900101-2/G, determinando que sejam os autos remetidos incontinenti ao E. Conselho Superior do Ministério Público, para apreciação, nos termos do Provimento 006 da PGJ e do art., $9^{\circ}, \S 1^{\circ}$, da Lei 7.347/85.

Antes da subida dos autos, intimem-se pessoalmente os indiciados e o DD. Presidente da Assembléia Legislativa do RS, com cópia desta promoção.

Remeta-se igualmente cópia desta Promoção do DD. Procurador-Geral da República, que deverá seguir a promoção de arquivamento do Expediente $\mathrm{n}^{\circ}$ SPI 16564-0900/01-2/D, também datada de hoje.

Porto Alegre, janeiro 28 ( $2^{\mathrm{a}}$ feira), 2002. 